\title{
Hubungan Pelaksanaan Program Usaha Kesehatan Sekolah Terhadap Perilaku Hidup Bersih Dan Sehat Pada Siswa SDN 13 Seberang Padang Utara
}

\author{
Nadia $^{\text {a }}$, Rika Sabria ${ }^{\mathrm{a}}$, Yonrizal Nurdina ${ }^{\mathrm{a}}$. \\ aProgram Studi Ilmu Keperawatan Universitas Andalas \\ e-mail : nadia_psik@yahoo.co.id
}

\begin{abstract}
School-age children is a critical age group because they are vulnerable of health issues. Health issues more dominant in school-age children are clean and healthy behavior. To encourage formation of the behavior required support from School Health Program (UKS) that the implementation not only focused on promotive and preventive efforts but also curative and rehabilitative. Howerver, at this time the implementation of the program was not maximal in Indonesia. The purpose of the research was to analyze the relationship between the school health program and clean and healthy behavior of students at SDN 13 Seberang Padang Utara. The research was a descriptive analytic study with cross sectional design.. The research was conducted from April 28 to May 5, 2012 with 98 samples consist of $4^{\text {th }}, 5^{\text {th }}$ and $6^{\text {th }}$ grade. The data was collected by using questionnaires and behavioral observation sheet. The result of data analysis by using a Chi-Square test showed that more than half of respondents have a clean and healthy behavior in medium category, most of respondents said the implementation of the school health program included in good category and there was a significant association between the implementation of the school health program with clean and healthy behaviors of students. Recommended to the schools and Seberang Padang health centers to be able to work together for the success of school health programs such as "little doctors" and BIAS.
\end{abstract}

Keywords : school health program, clean and healthy behavior, school-aged children

\begin{abstract}
Abstrak : Anak usia sekolah merupakan kelompok usia yang kritis karena seorang anak rentan terhadap masalah kesehatan. Isu kesehatan yang lebih menonjol pada anak usia sekolah adalah perilaku hidup bersih dan sehat. Untuk mendukung terbentuknya perilaku tersebut maka diperlukan dukungan dari Usaha Kesehatan Sekolah (UKS) yang dalam pelaksanaannya menitikberatkan pada upaya promotif dan preventif disamping juga upaya kuratif dan rehabilitatif. Namun saat ini pelaksanaan program UKS di Indonesia belum maksimal. Tujuan penelitian ini untuk mengetahui hubungan antara pelaksanaan program UKS terhadap perilaku hidup bersih dan sehat pada siswa SDN 13 Seberang Padang Utara. Penelitian ini adalah penelitian deskriptif analitik dengan design penelitian cross sectional. Penelitian ini dilakukan dari tanggal 28 April sampai dengan 5 Mei 2012 dengan jumlah sampel sebanyak 98 siswa, yang terdiri dari kelas 4, 5 dan 6. Pengumpulan data dilakukan menggunakan kuisioner dan lembaran observasi perilaku. Hasil analisa data yang menggunakan uji Chi-Square. menunjukkan bahwa lebih dari separuh responden berperilaku hidup bersih dan sehat kategori sedang, sebagian besar responden menyatakan pelaksanaan program UKS termasuk kategori baik dan terdapat hubungan yang bermakna antara pelaksanaan program UKS dengan perilaku hidup bersih dan sehat. Disarankan kepada pihak sekolah dan puskesmas Seberang Padang untuk dapat bekerja sama untuk menyukseskan program-program UKS seperti dokter kecil dan BIAS.
\end{abstract}

Kata kunci : program UKS, perilaku hidup bersih dan sehat, anak usia sekolah 
Anak usia sekolah merupakan kelompok usia yang kritis karena pada usia tersebut seorang anak rentan terhadap masalah kesehatan. Masalah kesehatan yang dihadapi oleh anak usia sekolah pada dasarnya cukup kompleks dan bervariasi. Peserta didik pada tingkat Sekolah Dasar (SD) misalnya, masalah kesehatan yang muncul biasanya berkaitan dengan kebersihan perorangan dan lingkungan, sehingga isu yang lebih menonjol adalah perilaku hidup bersih dan sehat, seperti cara menggosok gigi yang benar, mencuci tangan pakai sabun, dan kebersihan diri lainnya (Mikail, 2011).

Laporan Riset Kesehatan Dasar (RIKESDAS) Nasional tahun 2007, dapat disimpulkan bahwa perilaku yang menyangkut kebersihan dapat mempengaruhi kesehatan. Banyak penyakit yang dapat disebabkan karena perilaku hidup bersih dan sehat yang masih kurang seperti diare, kecacingan, masalah periodontal, filariasis, demam berdarah dan muntaber. Masalah kebersihan diri yang cukup banyak dialami oleh murid sekolah dasar yaitu : 86\% murid yang bermasalah pada gigi, $53 \%$ tidak biasa potong kuku, $42 \%$ murid yang tidak biasa menggosok gigi, dan $8 \%$ murid yang tidak mencuci tangan sebelum makan. Selain itu data penyakit yang diderita oleh anak sekolah terkait perilaku seperti cacingan adalah sebesar $60-80 \%$, dan caries gigi sebesar $74,4 \%$. Kompleksnya masalah kesehatan anak sekolah perlu ditanggulangi secara komprehensif dan multisektor (Depkes RI, 2008).

Selain rentan terhadap masalah kesehatan, anak usia sekolah juga berada pada kondisi yang sangat peka terhadap stimulus sehingga mudah dibimbing, diarahkan, dan ditanamkan kebiasaan - kebiasaan yang baik, termasuk kebisaan untuk berperilaku hidup bersih dan sehat. Untuk mendukung pencapaian hal tersebut, maka diperlukan dukungan dari Usaha Kesehatan Sekolah (UKS) yang dalam pelaksanaannya menitikberatkan pada upaya promotif dan preventif disamping juga upaya kuratif dan rehabilitatif yang berkualitas (Bahar, 2011). Usaha Kesehatan Sekolah dilaksanakan dalam tiga program pokok (TRIAS UKS) yang meliputi : pendidikan kesehatan, pelayanan kesehatan, dan pembinaan lingkungan sekolah sehat.

Melalui pelaksanaan program UKS ini diharapkan akan terbentuk pola pikir peserta didik yang terbiasa dengan perilaku hidup bersih dan sehat, dengan selalu memperhatikan kebersihan lingkungan sekolah, kebersihan pribadi, melakukan penghijauan, dan memanfaatkan fasilitas kantin sekolah yang bersih dan sehat. Keberhasilan program UKS sangat penting dalam meningkatkan prestasi belajar dan kesehatan peserta didik pada umumnya (Bahar, 2011). Menurut data dari Pusat Pengembangan Jasmani Depdiknas, baru sekitar 60\% Sekolah Dasar (SD) yang memiliki UKS dan dari jumlah tersebut baru $70 \%$ sekolah yang menjalankan program UKS (Depkes RI, 2005).

Berdasarkan fenomena di atas penulis ingin membahas tentang Hubungan Pelaksanaan Program Usaha Kesehatan Sekolah terhadap Perilaku Hidup Bersih dan Sehat pada Siswa SDN 13 Seberang Padang Utara tahun 2012.

Menurut Skinner (1938 dikutip dari Notoatmodjo, 2007) merumuskan bahwa perilaku merupakan respons atau reaksi seseorang terhadap stimulus (rangsangan dari luar). Faktor-faktor yang membedakan respons terhadap stimulus yang berbeda disebut determinan perilaku. Menurut Lawrene Green (1980 dikutip dari Notoatmodjo 2003), perilaku ditentukan 3 faktor yaitu: faktor pendukung (predisposing factors), faktor pemungkin (enabling factors), faktor penguat (reinforsing factors).

Perilaku hidup bersih dan sehat adalah perilaku kesehatan yang dilakukan atas kesadaran sehingga setiap orang dapat menolong dirinya sendiri di bidang kesehatan 
dan berperan aktif dalam kegiatan - kegiatan kesehatan di masyarakat (Depkes RI, 2007). Indikator perilaku hidup bersih dan sehat di sekolah adalah : jajan di kantin sekolah, mencuci tangan dengan air mengalir dan sabun, menggunakan jamban sehat, melakukan olahraga dan aktivitas fisik di sekolah, memberantas jentik nyamuk, menimbang berat badan dan mengukur tinggi badan sekali sebulan, tidak merokok di sekolah, dan membuang sampah pada tempatnya

Usaha Kesehatan Sekolah (UKS) adalah upaya terpadu lintas program dan lintas sektoral untuk meningkatkan kemampuan hidup sehat dan selanjutnya terbentuk perilaku hidup bersih dan sehat peserta didik, warga sekolah maupun warga masyarakat (Tim Pembina UKS Pusat, 2007). Menurut Departemen Pendidikan Nasional tahun 2006, terdapat tiga program pokok UKS (TRIAS UKS) antara lain pendidikan kesehatan, pelayanan kesehatan dan pembinaan lingkungan sekolah sehat.

Menurut Supandi (1992 dikutip dari Kawuryan 2006), tingkatan kelas di sekolah dasar dapat dibagi menjadi dua, yaitu kelas rendah dan kelas tinggi. Kelas rendah terdiri dari kelas 1, 2 dan 3, sedangkan kelas tinggi terdiri dari kelas 4, 5 dan 6. Anak usia sekolah pada kelas 4,5 dan 6 biasanya juga telah mempunyai perbendaharaan kata yang cukup sehingga memiliki kemampuan untuk membaca yang baik. Selain itu siswa pada kelas 4,5 dan 6 berada dalam tahap belajar, lebih mampu berkonsentrasi dalam menerima hal - hal baru dan lebih bertanggung jawab terhadap tugas - tugas yang diberikan bila dibandingkan dengan siswa kelas 1, 2 dan 3 yang masih lebih banyak dalam tahap bermain (Susumnaningrum, 2006).

\section{METODE}

Jenis penelitian ini adalah deskriptif analitik dengan desain penelitian cross sectional. Penelitian ini dilaksanakan dari tanggal 28 April sampai dengan 5 Mei 2012 di SDN 13 Seberang Padang Utara. Populasi penelitian ini adalah seluruh siswa SDN 13 Seberang Padang Utara pada tahun ajaran 2011/2012 yang berjumlah 210 orang. Sampel pada penelitian ini adalah seluruh siswa yang berada pada kelas 4, 5 dan 6 yang berjumlah 98 orang.

Pengumpulan data menggunakan kuisioner dan lembar observasi perilaku. Kuisioner terdiri dari 16 pertanyaan untuk variabel pelaksanaan program UKS dan 18 pertanyaan untuk variabel perilaku hidup bersih dan sehat. Lembaran observasi perilaku terdiri dari 18 pertanyaan yang meliputi 6 indikator perilaku hidup bersih dan sehat.

\section{HASIL DAN PEMBAHASAN}

Pengambilan data dilakukan selama 7 hari melalui pengisian kuesioner dan observasi perilaku hidup bersih dan sehat. Jumlah responden dalam penelitian ini berjumlah 98 orang dan sesuai dengan kriteria sampel yang ditetapkan. Responden yang berjenis kelamin perempuan sebanyak 46 orang dan laki - laki sebanyak 52 orang. Sebagian besar responden berusia antara 1012 tahun.

Berdasarkan penelitian yang telah dilakukan didapatkan data 43 responden $(43,9 \%)$ berperilaku hidup bersih dan sehat dengan kategori baik dan 55 responden $(56,1 \%)$ berperilaku hidup bersih dan sehat dalam kategori sedang. Pada penelitian ini hanya 6 indikator yang diukur sedangkan 2 indikator lagi, yaitu pemberantasan jentik nyamuk dan penimbangan berat badan dan pengukuran tinggi badan setiap bulan tidak diukur. Hal ini dikarenakan pemberantasan jentik nyamuk telah termasuk ke dalam program UKS dan penimbangan berat badan dan pengukuran tinggi badan setiap bulan tidak dilakukan. Penimbangan berat dan 
pengukuran tinggi badan hanya dilakukan sekali setahun yaitu pada awal tahun ajaran.

Berdasarkan hasil penelitian yang telah dilakukan di SDN 13 Seberang Padang Utara didapatkan bahwa dari 98 responden yang diteliti, terdapat 71 responden $(72,4 \%)$ yang menyatakan bahwa pelaksanaan program UKS termasuk dalam kategori baik dan 27 responden $(27,6 \%)$ menyatakan pelaksanaan program UKS termasuk dalam kategori sedang.

Hubungan Pelaksanaan Program Usaha Kesehatan Sekolah Terhadap Perilaku Hidup Bersih dan Sehat Siswa

Tabel 1. Hubungan Pelaksanaan Program Usaha Kesehatan Sekolah melalui TRIAS UKS Terhadap Perilaku Hidup Bersih dan Sehat Siswa

\begin{tabular}{|c|c|c|c|c|c|c|c|c|c|}
\hline \multirow{3}{*}{$\begin{array}{c}\text { Pelaksanaan } \\
\text { Program UKS }\end{array}$} & \multicolumn{6}{|c|}{$\begin{array}{l}\text { Perilaku Hidup } \\
\text { Bersih dan Sehat }\end{array}$} & \multirow{2}{*}{\multicolumn{2}{|c|}{ Jumlah }} & \multirow{3}{*}{$p$ value } \\
\hline & \multicolumn{2}{|c|}{ Baik } & \multicolumn{2}{|c|}{ Sedang } & \multicolumn{2}{|c|}{ Kurang } & & & \\
\hline & $\mathbf{f}$ & $\%$ & $\mathbf{f}$ & $\%$ & $\mathbf{f}$ & $\%$ & $\mathbf{f}$ & $\%$ & \\
\hline Baik & 38 & 53,5 & 33 & 46,5 & 0 & 0 & 71 & 100 & \multirow{2}{*}{0,002} \\
\hline Sedang & 5 & 18,5 & 22 & 81,5 & 0 & 0 & 27 & 100 & \\
\hline Kurang & 0 & 0 & 0 & 0 & 0 & 0 & 0 & 0 & \\
\hline
\end{tabular}

Data di atas menunjukkan bahwa jumlah responden yang berperilaku hidup bersih dan sehat dengan kategori baik hampir sebanding dengan responden yang berperilaku hidup bersih dan sehat dengan kategori sedang, walaupun telah sama-sama terpapar dengan pelaksanaan program UKS yang berkategori baik.

Keadaan ini sesuai dengan pendapat yang dikemukakan oleh Notoatmodjo (2007) yang menyatakan bahwa meskipun perilaku adalah bentuk respons atau reaksi terhadap stimulus atau rangsangan dari luar organisme (orang), namun dalam memberikan respons sangat tergantung pada karakteristik atau faktor - faktor lain dari orang yang bersangkutan. Hal ini berarti meskipun stimulusnya sama bagi beberapa orang, namun respon tiap orang berbeda - beda.

Peneliti berasumsi terdapat lima faktor yang mempengaruhi perilaku hidup bersih dan sehat responden masih termasuk dalam kategori sedang walaupun telah ditunjang dengan pelaksanaan program UKS dengan kategori baik, yaitu : pengetahuan, kesadaran diri responden, ketersediaan sarana dan prasarana di sekolah, dukungan keluarga, dan dukungan guru. Asumsi ini diperkuat oleh teori yang dikemukakan oleh Lawrence Green (1980 dikutip dari Notoatmodjo, 2003) yang menyebutkan bahwa perilaku ditentukan oleh 3 faktor utama, yaitu : faktor predisposisi, seperti pengetahuan, sikap, dan tradisi tentang kesehatan; faktor pemungkin, seperti ketersediaan sarana dan prasarana atau fasilitas untuk perilaku kesehatan; faktor pendorong, seperti dukungan dari guru, masyarakat setempat, dan petugas kesehatan.

Faktor yang pertama adalah pengetahuan. Notoatmodjo (2003) menyatakan bahwa tidak selalu pengetahuan yang baik akan selalu berkaitan dengan sikap positif, selain itu pengetahuan yang baik dan sikap positif belum menjamin individu berperilaku yang mendukung. Terdapat dua faktor yang mempengaruhi hal tersebut yaitu 
jumlah dan mutu informasi yang diterima dan besarnya kebutuhan untuk berperilaku. Jumlah dan mutu informasi yang diterima terkait dengan seberapa banyak informasi yang diluncurkan dan seberapa sering khalayak sasaran kontak dengan informasi, bagaimana informasi itu dihasilkan, dan seberapa efektif informasi itu bisa mengubah perilaku. Sedangkan besarnya kebutuhan untuk berperilaku berkaitan dengan seberapa besar masalah kesehatan tersebut dipersepsikan.

Faktor kedua adalah kesadaran diri responden. Peneliti berasumsi bahwa kesadaran diri yang rendah menjadi salah satu faktor perilaku hidup bersih dan sehat responden masih termasuk dalam kategori sedang. Hal ini sesuai dengan pendapat yang diungkapkan oleh Susumnaningrum (2006) yang menyebutkan bahwa responden yang merupakan anak usia sekolah dasar belum memiliki pendirian yang mantap dan kemampuan anak usia sekolah dasar masih rendah untuk mempertahankan sesuatu yang diyakininya sesuai dengan nilai-nilai kesehatan. Selain itu anak usia sekolah dasar masih mudah berubah karena pengaruh lingkungan termasuk peer group.

Faktor ketiga adalah ketersediaan sarana dan prasarana di sekolah. Green (1980 dikutip dari Notoatmodjo, 2003) menyebutkan bahwa ketersediaan fasilitas merupakan salah satu faktor penguat bagi seseorang untuk berperilaku. Terkadang walaupun seseorang tahu dan mampu untuk berperilaku sehat, tetapi tidak melakukannya karena tidak tersedianya fasilitas.

Faktor keempat adalah dukungan keluarga. Luthfianti (2008) menyebutkan bahwa pembentukan perilaku seseorang biasanya berawal dari keluarga. Dengan diawali dari kesadaran orang tua, khususnya ibu atau pengasuh untuk selalu membiasakan kebersihan terutama pada anak, akan membuat anak terbentuk sikap untuk menjadi bersih.
Faktor kelima adalah dukungan guru. Menurut Drs. A. Zubair, HAR, M.Si, Kadis Dikpora Kabupaten Bima, pola hidup bersih dan sehat harus dimulai dari guru, sehingga dapat dijadikan panutan dalam praktek keseharian, baik di lingkungan sekolah, keluarga maupun masyarakat. Pelaksanaan upaya perilaku hidup bersih dan sehat di sekolah secara langsung menggabungkan potensi orang tua, guru, dan tenaga kesehatan (Gunawan, 2012).

\section{KESIMPULAN DAN SARAN}

Berdasarkan hasil penelitian yang dilakukan mengenai hubungan pelaksanaan program UKS terhadap perilaku hidup bersih dan sehat siswa SDN 13 Seberang Padang Utara tahun 2012, maka dapat diambil kesimpulan bahwa lebih dari separuh responden berperilaku hidup bersih dan sehat dalam kategori sedang, sebagian besar responden menyatakan bahwa pelaksanaan program UKS termasuk dalam kategori baik, dan terdapat hubungan yang bermakna antara pelaksanaan program UKS dengan perilaku hidup bersih dan sehat siswa.

\section{DAFTAR PUSTAKA}

Bahar, Tatik. (2011). Upaya Pengembangan Promosi Kesehatan Pada Institusi Melalui Usaha Kesehatan Sekolah (UKS). Diakses pada tanggal 3 April 2012 dari http://tatikbahar.blogspot.com/2011/01/up aya-pengembangan-promosikesehatan.html

Departemen Kesehatan RI. (2007). Panduan promosi kesehatan di sekolah. Jakarta : Departemen Kesehatan RI. (2008). Pembinaan perilaku hidup bersih dan sehat di berbagai tatanan. Jakarta : Pusat Promosi Kesehatan.

Depkes RI. (2005). Baru 30\% SMP dan SMA Laksanakan UKS (Seri Kesehatan Masyarakat). Diakses pada tanggal 23 


Januari 2012 dari

http://www.depkes.go.id/popups/newswin dow.php?id=1149\&print=print.

Gunawan, Aris. (2012). Bima : Guru Berperan Penting Dalam Pola Hidup Bersih Dan Sehat. Diakses pada tanggal 11 Maret 2012 dari http://www.ampl.or.id/detail/detail01.php ?kode $=408 \& \mathrm{tp}=$ seminar\&kd_link $=1 \& \mathrm{kt}$

Luthfianti. (2008). Faktor-Faktor Yang Berhubungan Dengan Perilaku Mencuci Tangan Memakai Sabun Pada SiswaSiswi di MI Al Istiqomah dan SDN Kedaung Wetan Baru 2 Kota Tangerang Tahun 2008. Diakses pada tanggal 23 Juni 2012 dari http://lontar.ui.ac.id/file?file=digital/1230 91-S-5280-Faktor-faktor-Analisis.pdf Mikail, Bramirus. (2011). Anak Sekolah, Agen Perubahan Pola Hidup Sehat. Diakses pada tanggal 2 April 2012 dari http://health.kompas.com/read/2011/08/18 /15121480/ www.kompas.com

Notoatmodjo, Soekidjo. (2003). Pendidikan dan perilaku kesehatan. Jakarta : Rineka Cipta.

(2007). Promosi kesehatan dan ilmu perilaku. Jakarta : Rineka Cipta.

Susumnaningrum, Latifa Aini. (2006). Hubungan Faktor Individu dan Pola Asuh Keluarga Dengan Perilaku Hidup Bersih Dan Sehat Di Dua SD Kel. Kukusan Kec. Beji Depok, Jawa Barat. Diakses pada tanggal 8 Maret 2012 dari http://www.digilib.ui.ac.id/opac/themes/li bri/detail.jsp?id=96016\&lokasi $=$ lokal Tim Pembina UKS Pusat. (2007). Pedoman Pembinaan dan Pengembangan Usaha Kesehatan Sekolah. Jakarta : Departemen Kesehatan RI. 